\title{
PERANCANGAN WORKSHOP DAN GALERI SENI RUPA DENGAN PENDEKATAN ARSITEKTUR KONTEMPORER DI JAKARTA SELATAN
}

\author{
Misbahuddin' ${ }^{\text {, Soepardi Haris }}{ }^{2}$, Karya Widyawati ${ }^{3}$ \\ ${ }^{1}$ Universitas Indraprasta PGRI, Program Studi Arsitektur \\ mitsbah96@gmail.com \\ ${ }^{2}$ Universitas Indraprasta PGRI, Program Studi Arsitektur \\ soepardiharris@yahoo.co.id \\ ${ }^{3}$ Universitas Indraprasta PGRI, Program Studi Arsitektur \\ widyawatik@yahoo.co.id
}

\begin{abstract}
:
Planning the building of the Fine Art Workshop and Gallery to be able to accommodate all art activities in which there are art documentation activities, workshops, seminars and exhibitions for artists, or art lovers for art appreciation needs. And provide adequate facilities to exhibit and learn about fine arts.

Contemporary architecture used as an approach in this design. How the application can be realized in the form of contemporary architectural objects so that it can attract the public to come visit art workshops and galleries.
\end{abstract}

Key Words: Design, Workshop, Gallery, Fine Art, Contemporary Architecture

\begin{abstract}
Abstrak :
Perancangan bangunan Workshop dan Galeri Seni Rupa ini agar bisa mewadahi segala aktifitas seni rupa yang didalamnya terdapat kegiatan dokumentasi seni rupa, workshop, seminar dan pameran baik bagi para seniman, atau masyarakat penikmat seni unutk kebutuhan apresiasi seni. Serta memberikan fasilitas yang memadai untuk memamerkan maupun belajar tentang seni rupa. Arsitektur kontemporer dalam penerapanya dapat terwujud dalam bentuk objek arsitektur yang kekinian, dengan desain yang tidak sama seperti museum atau galeri pada umumnya yang menggunakan bekas bangunan lama, dengan bentuk-bentuk geometris yang menarik sehingga masyarakat tertarik untuk datang mengunujungi workshop dan galeri seni rupa.
\end{abstract}

Kata Kunci : Jurnal, Naskah, Panduan, Penulisan

\section{PENDAHULUAN}

Seiring berkembangnya seni rupa belakangan ini,sehingga muncul banyaknya seniman yang ada di Indonesia terutama di kota Jakarta yang menghasilkan karya dengan ciri khas dan aliranya masing-masing, banyaknya jumlah seniman di Jakarta sehingga menimbulkan masalah tersendiri bagi seni budaya di kota Jakarta. Dimana idealisme mereka berbeda sehingga selama ini terjadi beberapa kelompok atau komunitas yang berbeda sesama seniman di Jakarta, hal ini membuat perkembangan seni menjadi terbatas dan hanya diketahui oleh kelompok atau komunitas seni itu sendiri. Belum adanya ruang yang cukup atau fasilitas yang memadai untuk melakukan eksplorasi dan eksperimentasi berkesenian di kota Jakarta, sehingga pameran-pameran seni, pentas seni rupa atau pelatihan seni rupa, hanya digelar ditempat-tempat yang relatif kurang memiliki sarana yang memadai dan magnet untuk membuat masyarakat berdatangan untuk mengunjunginya

Sebuah wadah seni rupa harus mempunya 3 aspek fungsi utama pada bangunan yang akan di tuju, yakni fungsi apresiasi, edukasi, dan rekreasi
(Ambrose dan Crispin 1993). Fungsi apresiasi merupakan yang paling utama dimana sebuah karya seni dapat diapresiasi dan dinikmati oleh masyarakat umum, menjadikan masyarakat lebih menghargai dan menciptakaan rasa bangga akan hasil seniman Indonesia. Fungsi edukasi diharapkan masyarakat mampu belajar keanekaragaman seni rupa yang ada. Fungsi rekreasi juga sangat penting dimana menurut $D e$ Grasia merupakan aktifitas yang mengistirahatkan seseorang dari bekerja dan memberikan kepadanya suatu pemulihan serta perubahan saat bekerja kembali.

Dunia arsitektur selalu berkiblat pada kekinian atau yang bisa kita sebut kontemporer. Itu sebabnya mengapa gaya arsitektur selalu berubahubah dari dulu hingga sekarang setelah melalui berbagai upaya adaptasi dan akulturasi nilai, agama dan budaya dalam masyarakat. Peran arsitektur dalam proses produksi spasial dan proses perwujudan kembali, budaya membangun (spesifik) menjadi pertanyaan terbuka tanpa jawaban yang pasti, apalagi jika dikaitkan dengan dinamika transformasi dan perubahan cepat akibat 
globalisasi dan perkembangan teknologi media/informasi. Salah satu dampak dari globalisasi adalah tidak dapat dihindari adalah masuknya pemahaman dan konsep-konsep pembangunan, yang belum tentu sesuai dengan kondisi sosial, budaya masyarakat kita. Hal ini sering kali diikuti dengan munculnya berbagai persoalan lingkungan, akibat dari pendekatan pembangunan yang tidak berakar kepada konteks lokal. (Widjaja Martokusumo :Arsitektur Kontemporer Indonesia, Perjalanan Menuju Pencerahan).

Sehingga arsitektur kontemporer bisa dijadikan sebuah solusi dalam perancangan bangunan tentang bagaimana merespon isu tentang perkembangan zaman yang beriringan dengan kemajuan teknologi serta globalisasi pada saat ini.

\section{METODOLOGI}

Metode pendekatan perancangan yang digunakan adalah pendekatan kontemporer. Walaupun istilah kontemporer sama artinya dengan modern atau sesuatu yang up to date, tapi dalam disain kerap dibedakan. Istilah ini digunakan untuk menandai sebuah disain yang lebih maju, variatif, fleksibel dan inovatif, baik secara bentuk maupun tampilan, jenis material, pengolahan material, maupun teknologi yang dipakai.

Desain kontemporer menampilkan gaya yang lebih baru. Gaya lama yang diberi label kontemporer akan menghasilkan bentuk disain yang lebih segar dan berbeda dari kebiasaan. Misalnya, modern kontemporer, klasik kontemporer atau etnik kontemporer. Semua menyajikan gaya kombinasi dengan kesan kekinian.

Dalam pendekatan kontemporer ada beberapa hal yang di pelajari, antara lain :

\section{Prinsip Arsitektur Kontemporer}

\section{a. Prinsip rasional}

- Koordinasi dari unit-unit dalam massa bangunan

- Penentuan dimensi elemen-elemen yang sesuai skala manusia.

- Sistem Struktur

- Semua elemen-elemen di atas harus mampu menampilkan sesuatu logika tertentu; pengungkapan struktur bangunan; proporsi; dan sistem struktur yang jelas.

b. Prinsip simbolik

- Kebenaran artistic.
- Kekuatan persepsi.

- Proses kontemporer suatu bangunan harus menampilkan: proporsi, irama, dimensi, ornamen, warna, iluminasi dan bahan.

c. Prinsip psikologi

Prinsip psikologi merupakan perwujudan dan kombinasi dari dua prinsip di atas, prinsip ini sendiri cenderung terus berubah-ubah sesuai tahap bahkan cenderung berulang-ulang. Dari sinilah pentingnya suatu gagasan/pemecahan yang mampu memberi dan menjawab permasalahan dikemudian hari.

\section{Penerapan Arsitektur Kontemporer}

Pada konsep kontemporer terlihat pada konsep ruang yang terkesan terbuka atau open plan, harmonisasi ruangan yang menyatu dengan ruang luar, memiliki fasad yang terbuka. Arsitektur ini dikenal lewat karakter desain yang praktis dan fungsional dengan pengolahan bentuk geometris yang simple dan warna-warna netral dengan tampilan bersih. Penggunaan jendela yang besar, serta kombinasi bentuk yang unik dan aneh. Banyak menggunakan material alam, detail-detail bergaris lurus. Berikut beberapa penerapan arsitektur kontemporer dalam desain. (Schirmbeck, 1988)

a. Memasukan cahaya kedalam ruangan.

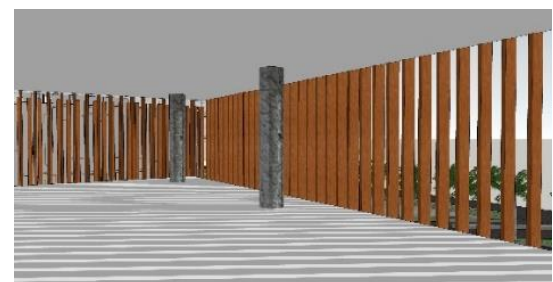

b. Konsep open plan.

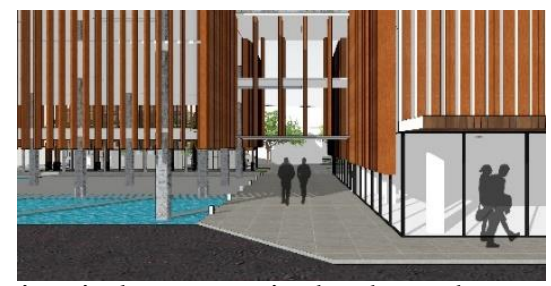

c. Dominasi elemen garis dan bentuk geometris.

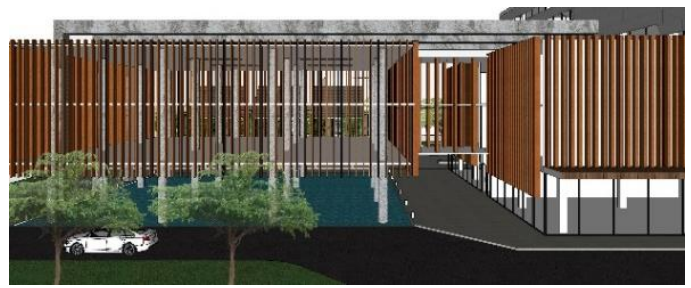




\section{HASIL DAN PEMBAHASAN}

\section{Tema Rancangan}

Tema yang digunakan dalam perancangan ini adalah simbiosis, Simbiosis dalam arsitektur bisa diartikan sebagai hubungan antara dua fungsi atau lebih, yang dapat berdiri sendiri namun juga dapat berinteraksi antara keduanya dan dapat saling menguntungkan. Mengambil tema simbiosis dari hubungan antara workshop sebagai tempat pelatihan karya seni dengan galeri sebagai tempat memamerkan karya seni, seniman sebagai pembuat karya seni dengan masyarakat sebagai pemberi apresiasi seni, dan masa lalu dengan masa sekarang.

Ada dua unsur yang paling penting dari simbiosis, yaitu konsep "sacred zone (Zona suci)" dan "intermediary space (Ruang penengah)" kedua unsur inilah yang merupakan hal yang diperhatikan dalam pembentukan simbiosis, yaitu:

\section{a. Zona suci}

Dalam simbiosis tidak ada peleburan antara dua nilai atau fungsi yang berbeda kedalam sesuatu yang baru. Karena dalam simbiosis, nilai-nilai asli suatu zona/ruang tetap dipertahankan.

b. Ruang penengah

Ruang penengah, bersifat dinamis yaitu pembentukan zona sementara antara dua elemen yang bertentangan. Dapat juga dikatakan sebagai zona ketiga yang dibuat untuk memenuhi tujuan menengahi kedua elemen tersebut. Merupakan penghubung antara workshop dan galeri.

\section{Lokasi Proyek}

Lokasi proyek berada di Jl. Ampera, Jakarta selatan merupakan lokasi yang cukup strategis, yaitu terletak di kawasan pendidikan, perkantoran, dan pemukiman Pemilihan lokasi proyek di Jakarta selatan ini jika dilihat dari segi aksesibilitas dan kawasan, dinilai cukup strategis dan memiliki potensi yang besar untuk perkembangan seni rupa.

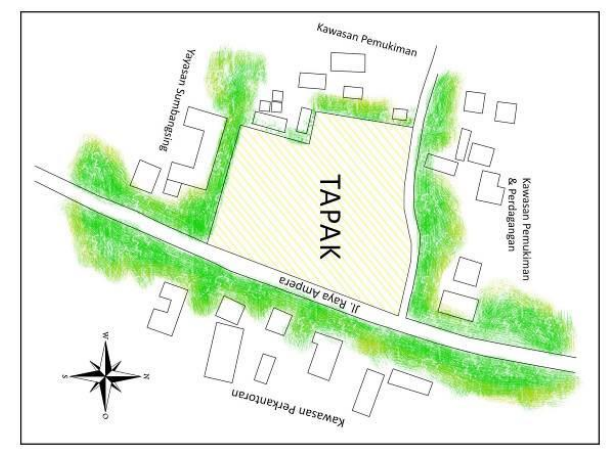

Gambar 1. Lokasi Tapak
Berikut adalah data teknik lokasi tapak :

1. Luas Tapak: $1,7 \mathrm{Ha}$

2. KDB : $30 \%$

3. KLB : 2

4. $\mathrm{KDH}: 40 \%$

5. GSJ $: 10 \mathrm{~m}$

6. Peruntukan : Olah raga dan rekreasi

\section{Analisis Tapak}

\section{Kondisi Existing Tapak}

Jalan raya Ampera merupakan jalur penghubung Cilandak dan kuningan. Kondisi kontur tanah pada tapak relative datar, dengan kemiringan $0-0,25 \%$.

Kondisi tapak masih berupa lahan kosong dan sebagian lahan usaha perdagangan. Disekitar tapak sebagian besar adalah permukiman penduduk dengan tingkat kepadatan sedang, dan area perkantoran.

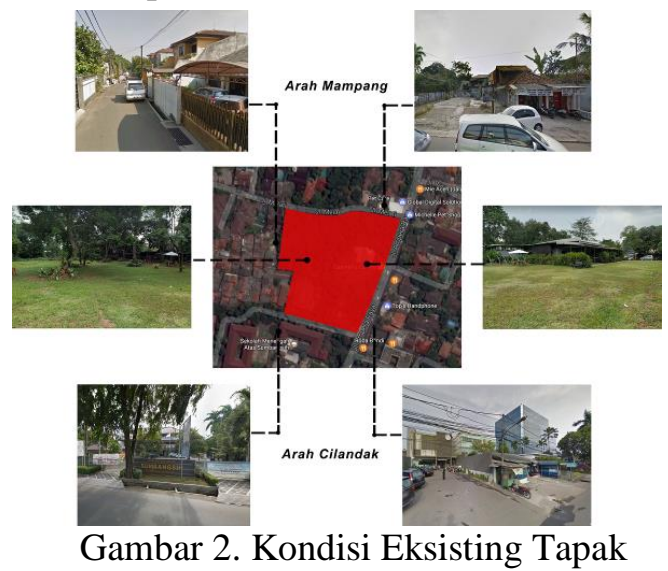

\section{Konfigurasi Tapak}

Dilihat dari lokasi tapak yang berada di jl. Ampera yang dikelilingi pemukiman warga, perkantoran serta sarana pendidikan. Dan hanya ada satu jalan utama Maka untuk mencapai lokasi tapak yang dilalui kendaraan hanya mempunyai satu akses yaitu Jl. Ampera.

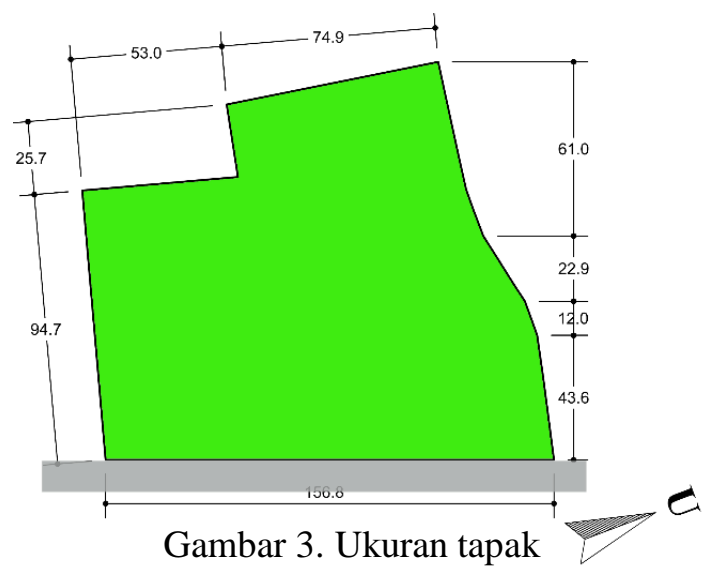


Tapak yang merupakan lahan kosong berbentuk persegi yang tidak sempurna karena batas-batas yang ada ditapak. Dengan bentuk seperti itu mempunyai kelebihan yaitu memudahkan proses perancangan dimana untuk meletakan massa serta akses keluar masuk ke dalam tapak karena hanya memiliki jalan utama yang berada didepan tapak.

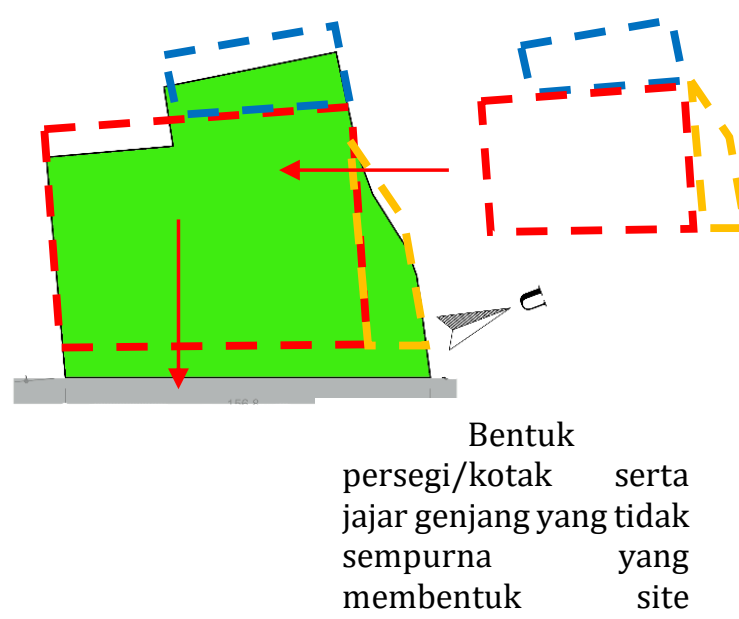

Gambar 4. Kondisi Eksisting Tapak

\section{Pencapaian}

Pencapaian ke dalam tapak bisa diakses dengan menggunakan kendaraan pribadi maupun kendaraan umum seperti angkot maupun metromini, karena tapak berada dijalan utama dan mudah dicapai.

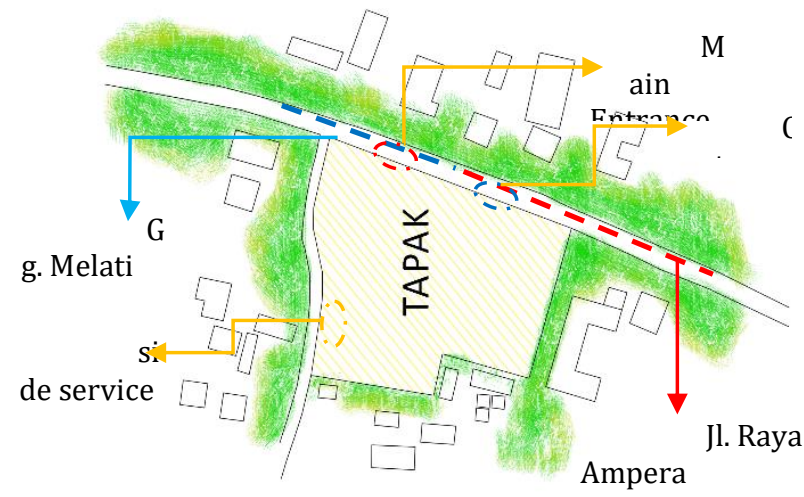

Gambar 5. Pencapaian

Jl. Raya Ampera yang dilewati angkutan umum serta kendaraan pribadi yang merupakan jalan utama untuk mencapai tapak, dengan lebar jalan $8 \mathrm{~m}$. kondisi jalan dua arah dengan kondisi jalan yang cukup padat terutama pada pagi dan sore hari. Sedangkan Gg. Melati merupakan jalan sekunder yang berada disekitar tapak, bisa diakses oleh mobil dengan lebar jalan $3.5 \mathrm{~m}$, cukup sempit apabila ada dua mobil berpapasan.

\section{Pencahayaan}

Arah sinar matahari searah dengan akses utama pada site. Pada pagi hari area depan tapak yang terasa panas, sedangkan pada sore hari area belakang tapak yang terasa panas.

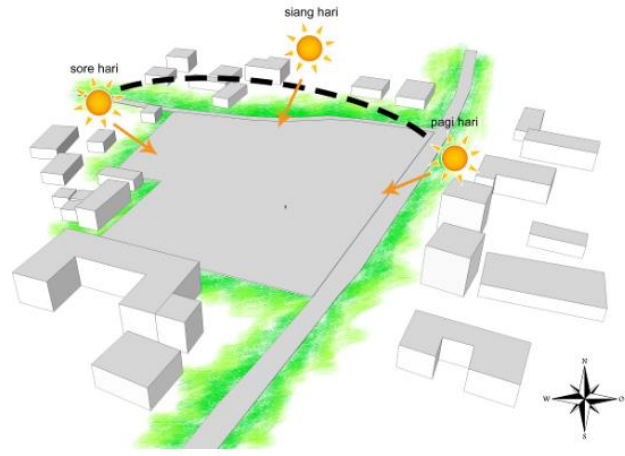

Gambar 6. Arah matahari terhadap tapak

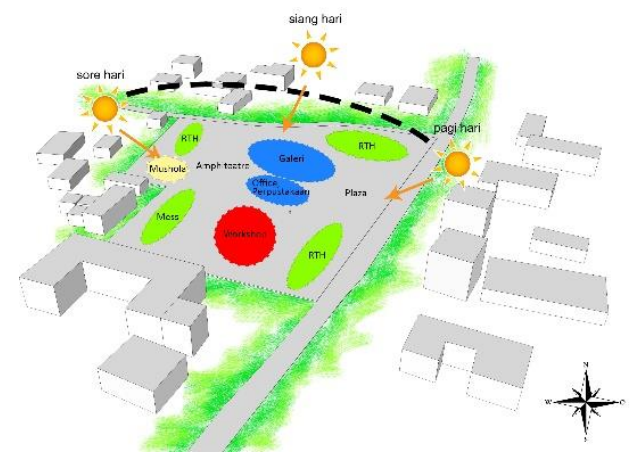

Gambar 7. Area yang terkena sinar matahari langsung

Ruang galeri, workshop , office, perpustakaan diletakan ditengah site, menghadap ke arah timur dan dikelilingi bangunan lain serta ruang terbuka hijau, untuk masa yang terpisah seperti mess dan masjid diletakan dibelakang site menghadap ke bangunan utama dan membelakangi matahari sore sehingga meminimalisir panas yang terjadi pada sore hari.

Pada bangunan diberi second skin untuk meminimalisir panas yang masuk ke dalam bangunan tetapi tetap mendapatkan cahaya matahari sebagai pencahayaan alami. Dibawah ini gambaran solusi pada desain terhadap sinar matahari langsung 


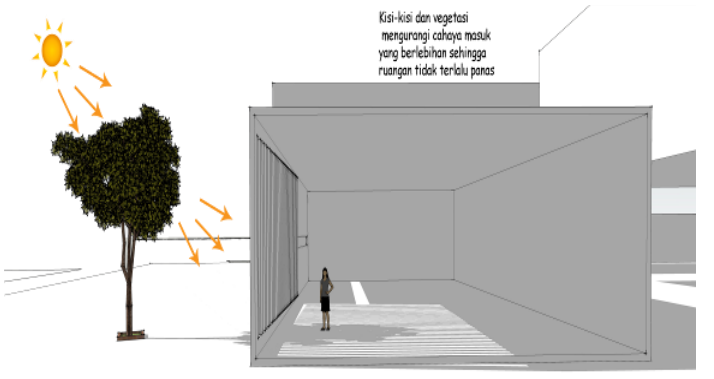

Gambar 8. Solusi terhadap desain

Untuk membantu menstabilkan suhu tinggi akibat sinar matahari, Dapat dilakukan dengan menambahkan unsur air pada site. Serta memberikan kisi-kisi terhadap fasad bangunan yang terkena sinar matahari langsung, sehingga sinar matahari yang masuk kedalam ruanganbisa dikurangi intensitasnya agar tidak menyebabkan suhu ruangan terasa panas, dan juga di area sekitar bangunan ditanami vegetasi untuk sehingga area yang terkena sinar matahari langsung bisa diminimalisir.

5. Penghawaan

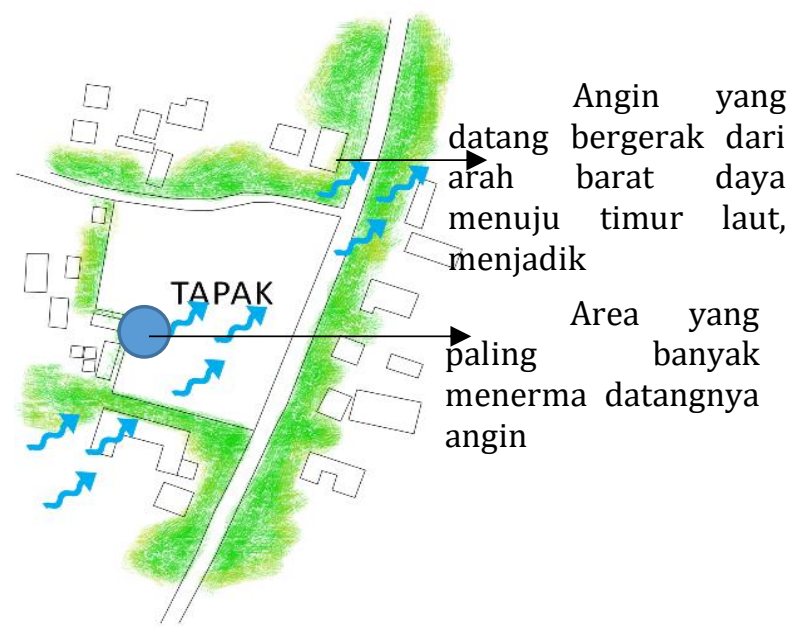

Gambar 9. Arah angin

Memanfaatkan angin untuk menurunkan suhu dan kenyamanan thermal didalam bangunan, Pada bangunan ini menerapkan sistem penghawaan alami dengan menggunakan bukaan-bukaan pada massa bangunan dengan memperhatikan arah datang angin.

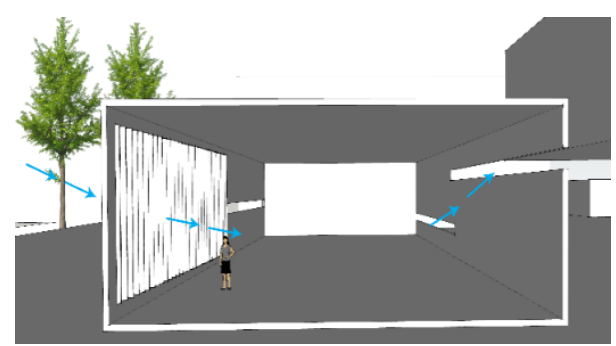

Gambar 10. Solusi penghawaan alami

\section{Lahan terbangun}

Lahan yang berlokasi di jalan Ampera, Jakarta selatan mempunyai peraturan yang sudah ditetapkan oleh pemda DKI Jakarta tentang peraturan bangunan, diantaranya sebagai berikut :

Luas Tapak: 1,7 Ha

$\begin{array}{ll}\text { KDB } & : 30 \% \\ \text { KLB } & : 2 \\ \text { KDH } & : 40 \% \\ \text { GSJ } & : 10 \mathrm{~m}\end{array}$

Peruntukan : Olah raga dan rekreasi

Perhitungan luas

Luas lahan : $17.230 \mathrm{~m}^{2}$

KDB $\quad: 17.230 \times 30 \%=5169 \mathrm{~m}^{2}$

KLB $\quad: 17.230 \times 2=34.460 \mathrm{~m}^{2}$

Jumlah lantai: $34.460 / 5169=6$ lantai

$\mathrm{KDH} \quad: 17.230 \times 40 \%=6.892$

\section{Analisa Iklim}

Wilayah Jakarta selatan beriklim panas dengan suhu rata-rata pertahun $27^{\circ} \mathrm{C}$, dan pada siang hari mampu mencapai $35^{\circ} \mathrm{C}$ yang harus ditoleransi oleh warga Jakarta sendiri. Dengan tingkat kelembaban berkisar antara 80-90\% Arah angin dipengaruhi angina Muson Barat terutama pada bulan Mei-Oktober.

\section{Penzoningan}

Dalam penzoningan dibagi menjadi 4 zona yaitu, publik, semi privat, privat, dan service.

a. Zona Publik

Zona ini terdiri dari parkiran, Taman, Ampiteater, serta prasarana lainya.

b. Zona Semi private

Zona ini terdiri dari ruang pameran, ruang seminar, workshop, perpustakaan, retail shop, restoran.

c. Zona Privat

Zona ini terdiri dari kantor pengelola, laboratorium, ruang penyimpanan, ruang keamanan. 
d. Zona Service

Zona ini merupakan tempat pembuangan sampah.

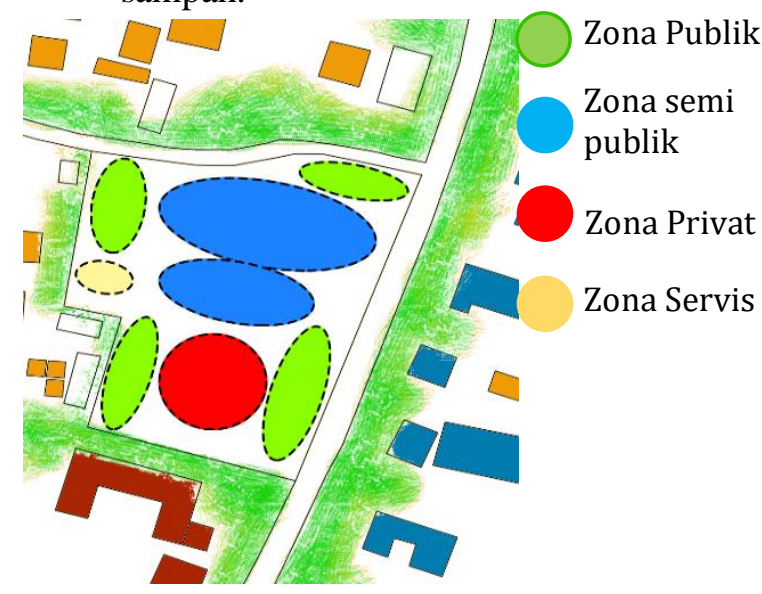

Gambar 11. Penzoningan

\section{Transformasi Bentuk}

Ide dasar diambil dari bentuk geometri yang merupakan prinsip arsitektur kontemporer yang diolah melalui pendekatan metafora tangible dari ikan hiu dengan ikan remora, seperti sebuah simbiosis komensalisme dimana workshop mendapat keuntungan dari adanya galeri, tetapi galeri tidak dirugikan ataupun diuntungkan dengan adanya workshop.
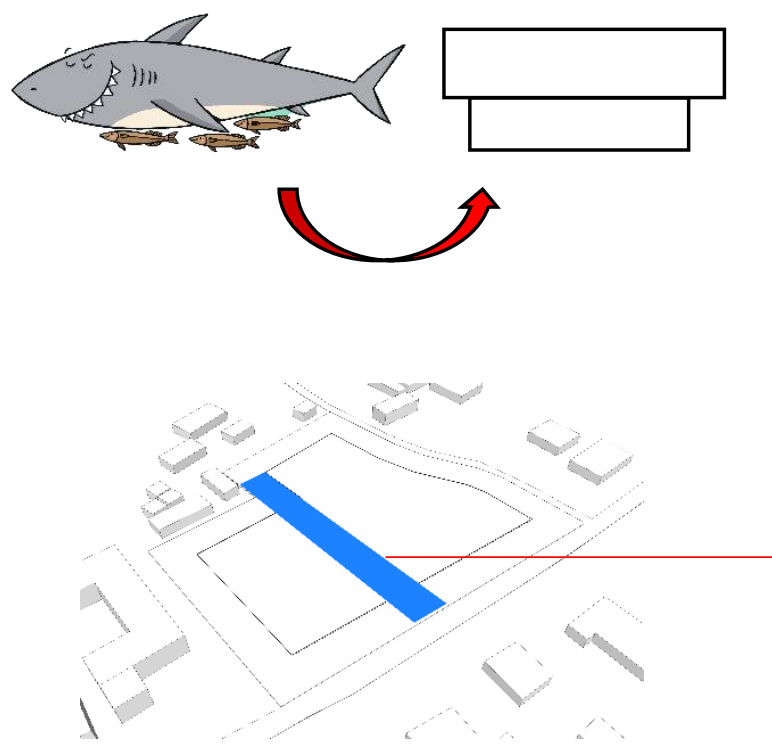

Ruang penghubung antara workshop dan galeri, space cut.
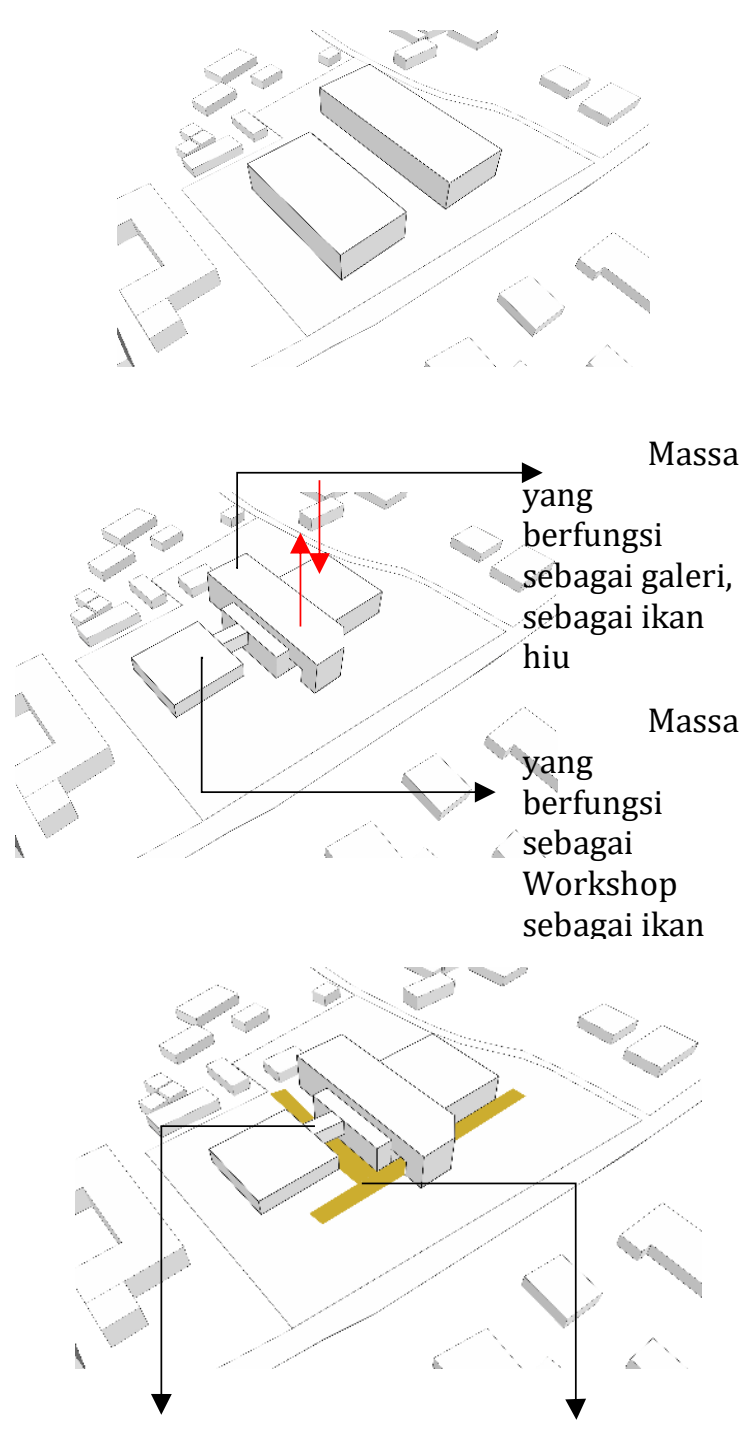

Ruang penghubung antara workshop dan galeri Space cut untuk sirkulasi sebagai intermediary space pejalan kaki

Gambar 12. Transformasi Bentuk

Desain

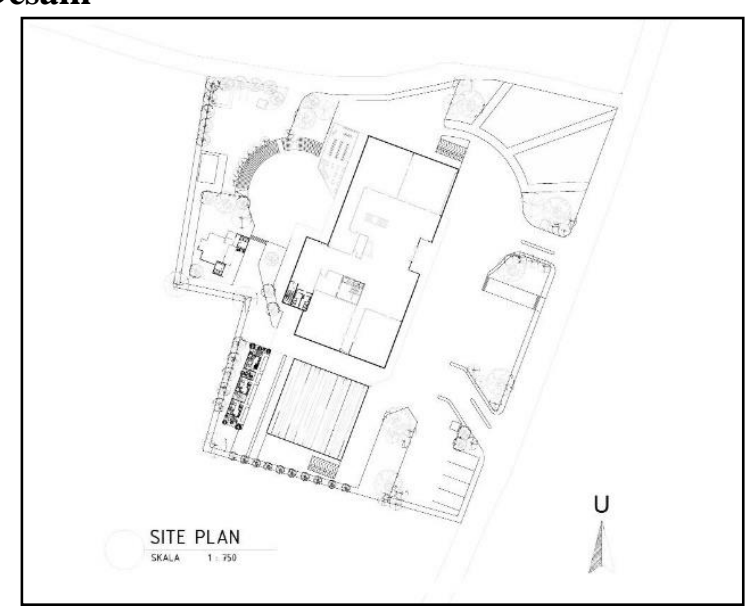

Gambar 13. Site Plan 

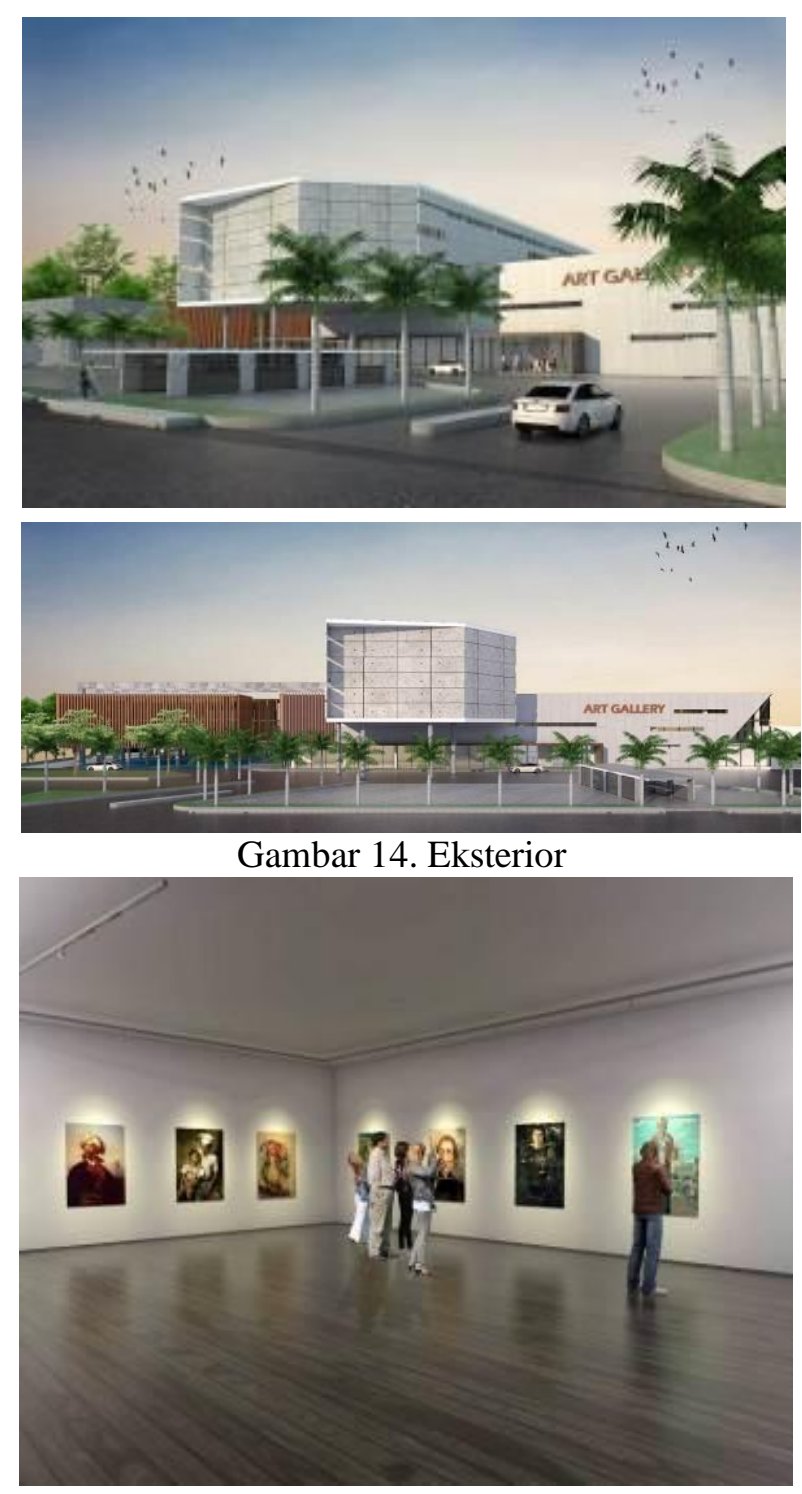

Gambar 15. Interior

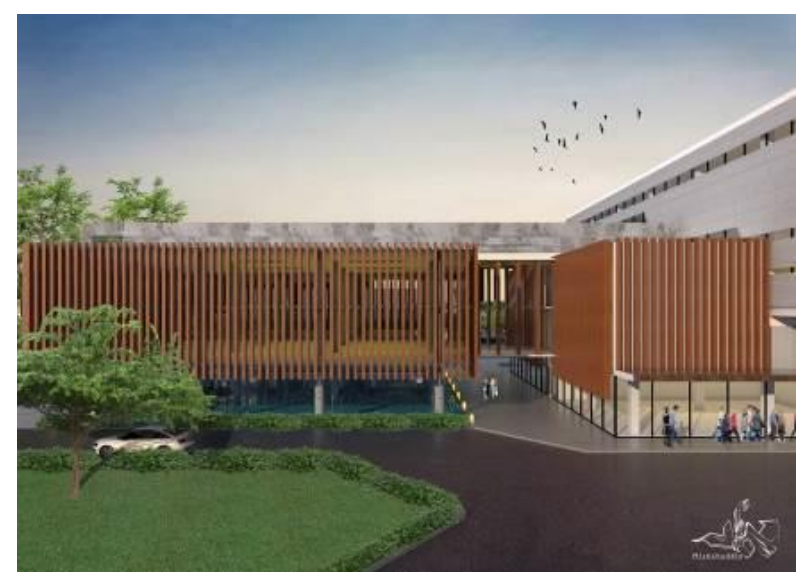

Gambar 16. Detail Arsitektur

\section{PENUTUP}

Simpulan

Workshop dan galeri seni rupa ini sebagai wadah bagi para seniman untuk berkarya serta memamerkan karyanya kepada publik dan mendapatkan apresiasi dari sesama seniman maupun dari masyarakat, serta menjadikan daya tarik masyarakat untuk mengunjungi dan mengenal seni rupa. Bangunan workshop dan galeri seni rupa ini menggunakan pendekatan arsitektur kontemporer dengan menerapkan prinsip-prinsip arsitektur kontemporer dalam desain seperti memasukan cahaya matahari kedalam ruangan sebagai pencahayaan alami serta sebagai estetika dengan mengatur cahaya yang masuk menjadi sedemikian rupa, kemudian prinsip open plan yang diterapkan dalam desain yang berupa ruang terbuka diantara dua fungsi bangunan antara workshop dan galeri, selanjutnya

dengan bentuk-bentuk geometris yang diterapkan dalam desain sebagai masa bangunan yang di padukan dengan unsur garis vertikal maupun horizontal sebagai pembentuk fasad bangunan. Bangunan ini didesain menjadi bangunan yang kekinian yang dapat menarik minat masyarakat untuk datang berkunujung ke galeri seni rupa.

Simbiosis mutualisme yang tercipta pada perancangan ini antara workshop dan galeri, dimana workshop merupakan tempat pelatihan karya seni sedangkan galeri merupakan tempat memamerkan karya seni, seniman sebagai pembuat karya seni dengan masyarakat sebagai pemberi apresiasi seni, serta simbiosis antara masa lalu dengan masa sekarang, dimana masa lalu merupakan karya seni yang sudah ada sebelumnya yang di pamerkan pada masa sekarang di sebuah bangunan yang memiliki konsep kekinian yang menjadikan galeri tersebut sebuah wadah untuk menampung semua simbiosis itu. Bentuk bangunan juga dibuat mengikuti tema yang dipakai, sehingga antara bangunan satu dengan bangunan lainya saling berhubungan dan saling memberikan timbal balik antar fungsinya.

\section{Daftar Pustaka}

Neufert, Ernest, (2002). Data Arsitek Jilid II Edisi 33, Terjemahan Sunarto Tjahjadi, Ferryanto Chaidir, Jakarta : Penerbit Erlangga.

Panero, Julious \& Zelnik, Martin, (1979). Dimensi Manusia dan Ruang Interior.

United states : Whitney Library and Design.

Egan, D. (1983). Architectural Lighting. New York: McGraw-Hill.

Ching, D.K, (2008). Bentuk dan Susunan Ruang, Jakarta : Penerbit Erlangga. 
Darragh, Joan \& Synder. S James, (1993). Museum Design Planning and Building For Art, New York : Oxford University Press.

Adiwibowo, S Retnasih, (2015, Oktober, 19). Isu Kontemporer Dalam Arsitektur ndonesia. Oktober, 27, 2016, http://www.scribd.com/document/213088668 / Isu-Kontemporer-Dalam-ArsitekturIndonesia.html

Abdillah D.P, Syuri, M, (Oktober, 10, 2018). Metode Perancangan Kisho Kurokawa. Desember,15,2017, http://www.scribd.com/document/239181233 /metode-perancangan-kisho-kuroawa.html

Badan Pusat Statistik Kota Jakarta, (2017, Juli, 11) Jumlah penduduk berdasarkan usia, Februari, 20, 2018, website: http://data.jakarta.go.id/dataset/data-jumlah penduduk-provinsi-dki-jakarta-berdasarkankelompok-usia-perkelurahan/resource/a110d684-3169-4d02a665-feb072d52dc5.html

Martokusumo, Widjaja, ( 2016, Maret, 31). Arsitektur Kontemporer Indonesia, Perjalanan Menuju Pencerahan. September, 27, 2016, https://www.scribd.com/document/36160529/ Arsitektur-Kontemporer-IndonesiaPerjalanan-Menuju-Pence-Rah-An 